\title{
Conception Rates of Holstein-Friesian Cows Inseminated Artificially with Reducing Frozen Semen Doses
}

\author{
A. Anggraenia, ${ }^{a}$, T. Herawati ${ }^{a}$, L. Praharani ${ }^{a}$, D. Utami ${ }^{b}$, \& A. Argis ${ }^{b}$ \\ Indonesian Research Institute for Animal Production \\ Jalan Veteran III, PO. BOX 221 Ciawi Bogor 16002, Indonesia \\ ${ }^{\mathrm{b}}$ Artificial Insemination Center Lembang, \\ Jalan Kiwi Kayu Ambon No. 78, Lembang, Indonesia \\ (Received 25-09-2015; Reviewed 02-02-2016; Accepted 20-06-2016)
}

\begin{abstract}
Conception rates of Holstein Friesian (HF) acceptors were evaluated in artificial insemination (AI) mating using three frozen semen doses of the straws per volume of $0.25 \mathrm{cc}$. Frozen semen consisted of a standard dose by $25 \times 10^{6}$ sperms (L.1) and two reduced doses by $20 \times 10^{6}$ sperms (L.2) and $15 \times 10^{6}$ sperms (L.3). This field study was conducted in dairy cattle area of Lembang NBMCU, from August 2011 to March 2012. Frozen semens were obtained from two HF national progeny tested young bulls. Conception was detected by rectal palpation, around 60-90 days after AI mating. Conception rates (CR $\%)$ were calculated as a ratio between pregnant acceptors to the total AI mated cows. Some general linear model analyzes were conducted by considering fixed variables of semen dose (3), bull (2), inseminator (6) and parity (5). The results showed that three frozen semen doses did not significantly affect $(P>0.05)$ on CR (\%). By decreasing semen dose to L.3 gave CR (\%) similar to L2 even to L1. It was concluded that frozen semen doses of HF bulls at the levels of 20 million to 15 million sperms per straw per volume of $0.25 \mathrm{cc}$ resulted CR (\%) similar to the standard one.
\end{abstract}

Key words: insemination, semen dose, conception rates

\section{ABSTRAK}

Angka konsepsi sapi Friesian Holstein (FH) betina sebagai akseptor dievaluasi pada perkawinan inseminasi buatan (IB) menggunakan 3 dosis semen beku dari straw per volume $0,25 \mathrm{cc}$. Semen beku terdiri atas dosis standar mengandung 25 juta sperma (L.1) serta 2 dosis yang diturunkan dengan kandungan 20 juta sperma (L.2) dan 15 juta sperma (L.3). Studi lapang ini dilakukan di sentra sapi perah KPSBU Lembang, dari Agustus 2011 sampai Maret 2012. Semen beku berasal dari dua pejantan FH hasil progeni tes nasional. Kebuntingan dideteksi secara palpasi rektal, sekitar 60-90 hari setelah IB. Angka konsepsi atau conception rates (CR \%) dihitung sebagai rasio antara jumlah sapi akseptor yang bunting terhadap jumlah sapi yang di-IB. Beberapa Model Linier Umum diterapkan dengan variabel tetap meliputi dosis semen (3), pejantan (2), inseminator (6), dan paritas (5). Ketiga dosis semen beku tidak berpengaruh nyata terhadap angka CR (\%). Penurunan dosis semen beku sampai dosis L.3 menghasilkan CR yang sama baik dengan L.2, bahkan dengan L.1. Disimpulkan bahwa semen beku pejantan FH dengan dosis 20 juta sampai 15 juta sperma per staw per 0,25 cc menghasilkan angka konsepsi sapi akseptor yang sama baiknya dengan konsentrasi standar.

Kata kunci: inseminasi, dosis semen, angka kebuntingan

\section{INTRODUCTION}

Artificial insemination (AI) has become a way of mating offering many advantages, such as to accelerate genetic improvement of livestock and to serve estrous females in a large number and a wide scale, so

*Corresponding author:

E-mail: ria.anneke@yahoo.co.id
AI mating provides promising economic benefits. A bull through a wide use of his frozen semen can serve several hundreds or even thousands of estrous cows in one year. This mating therefore is powerful to exploit maximum advantages of top bulls in dairy cattle industry (Bucher et al., 2009). Around 60\% of breeding cattle population have been globally using AI mating in the effort to distribute widely superiority of the best bulls. Distribution of top bulls by AI mating in the dairy cattle industry can considerably be higher (Bhakat et al., 2011). 
In frozen semen industry, the number of spermatozoa per straw are crucial that can result in a high fertility of cows as AI acceptors (DeJarnette et al., 2010). The success of AI mating using frozen semen at lower doses, from which the ability to give conception rates of acceptors similar to that of the standard dose, could maximize the use of superior bulls through the production of their straws (Andrabi et al., 2006). Artificial insemination using frozen semen instead of fresh semen, however, required number of sperm per dose of insemination for achieving a good fertility of AI acceptors (Saha et al., 2014). A field study in dairy cattle for the purpose of investigating the effectiveness of AI frozen semen mating at a low dose (15 million sperms) and a very low dose ( 2 million sperms) on straws per volume 0.25 cc was conducted by Anderson et al. (2004). The result showed that the previous dose of 15 million sperms was capable of achieving optimal conception rates of the acceptors, whilst the latter one of 2 million sperms failed to maintain and caused a decreasing conception rates of the acceptors.

Further developments of using frozen semen in the AI mating have been conducted, particularly in dairy cattle and beef cattle in regards to accelerate the increased specific sexed population. One of purposes for combining the use of frozen sperm with sexing technology in AI mating is for getting a faster genetic progress of breeding stocks. To determine the minimum level of sex-sorted frozen sperm dose in achieving optimal conception rates in dairy cattle and beef cattle, many studies have been done such as by Seidel \& Schenk (2008), Schenk et al. (2009), Frijters et al. (2009), DeJarnette et al. (2010), Larson et al. (2010) and Sá Filho et al. (2010). DeJarnette et al. (2010), as an example, compared conception rates of Holstein cows and heifers in AI mating by $2.1 \times 10^{6}$ or $3.5 \times 10^{6}$ sex-sorted sperms. Conception rates of both of the sexed frozen semen doses were comparable. Further, some field results are seemingly prospects for improved efficiency of sex-sorting semen procedures with lower frozen semen doses for commercial application in the dairy cattle industry.

HF dairy cattle in Indonesia for their mating system are almost entirely using AI mating with frozen semen produced by National Artificial Insemination Agencies. To maintain the genetic quality of HF dairy cattle, identification of superior HF domestic bulls has been done through the National Progeny Test. Frozen semen of HF bulls produced by Lembang Artificial Insemination Agency (Lembang AIA), as one of the two National Artificial Insemination Centers, up to now has still been implementing a standard concentration of straw per volume 0.25 cc containing around 25 million sperms. Frozen semen from the National Progeny Tested bulls are targeted to be produced more efficiently. This might be realized, among others, through the production of more frozen semen straws per collection per bull. This can be realized if the number of frozen semen per straw can be produced at lower levels of concentration over the current standard, but they are still capable of giving conception rates of $\mathrm{AI}$ acceptors as well as to the standard one. Another important consideration is that if optimum doses of sex-sorted frozen sperms per straw for AI mating can be determined at field in dairy cattle, so these sexed-sorted frozen semen for AI mating can be expected for getting a wider application in beef cattle and buffalo as well.

This study, therefore was conducted to obtain information on the effectiveness of using different frozen semen concentrations at the volume $0.25 \mathrm{cc}$ produced by Lembang AIA in artificial insemination mating, providing two lowered frozen sperm doses $\left(20 \times 10^{6}\right.$ sperms and $15 \times 10^{6}$ sperms) compared to the standard one $(25 \times$ $10^{6}$ sperms) on conception rates of HF acceptors at small dairy farmers in Lembang, West Java.

\section{MATERIALS AND METHODS}

\section{Location and Period}

This field research for studying three different doses of frozen semen by AI mating was conducted from August 2011 to March 2012. Research location was done in small dairy farmers, mostly raising Holstein Friesian (HF) dairy cattle under semi intensive management. These small farmers in raising HF dairy cattle were distributed in a number of locations under Lembang North Bandung Milk Collecting Unit (Lembang NBMCU), Lembang Subdistrcit, Lembang, West Java.

\section{Frozen Semen}

Three different doses of frozen semen were produced by Lembang AIA by following various standard processes of collection, evaluation, dilution, processing and packaging as usually done (Lembang AIA, 2011). An artificial vagina was used to shelter fresh semen. Macroscopic examination was done for volume, color and consistency; microscopic was analyzed for mass and individual movements by microscope; and examination of concentration was conducted by spectrophotometer. Semen dilution was performed with an equilibration time of $5 \mathrm{~h}$. Calculation of concentration of sperm per collection of fresh semen per bull used this formula:

Number of straw $=$ (semen volume $\mathrm{x}$ motility $\mathrm{x}$ sperm concentration) / Straw concentration

This study of three different doses of frozen semen used straws with volume $0.25 \mathrm{cc}$, consisting of Level I for a standard dose containing 25 million sperms, Level II as the first reduced sperm dose containing 20 million sperms and Level III as the second reduced sperm dose containing 15 million sperms.

\section{Bull}

Two HF bulls as participants of National Progeny Test were used as producers of frozen semen, namely Farrell (No. Code: 30 686) and Forsa (No. Code: 30 698). Both males were descendants of ancestors with high genetic potential of milk production as well as good growth, reproduction and libido. 


\section{Acceptor}

AI acceptors were HF dairy cows and heifers, with a minimal number of acceptors subjected for each combination based on classes of sperm concentration (3) and males (2) were approximately 50 animals. So that a total number of AI acceptors for all of dose and male combinations were targeted at a minimum number by around 300 heads. These cows were identified for having good body condition, normal reproductive organ and healthy, as well as clear signs of estrus at the time of estrus coming. Cows were also not in disorder reproduction and repeat breeder. These HF cows considered as candidates of AI acceptors were within 1-8 parities (556 heads). Most of them were in 1-4 parities for 517 heads (93\%), while the rest were in 5-8 parities for 39 heads (7\%).

\section{Inseminator}

Artificial insemination services were conducted by six inseminators having AI operating area surrounding HF dairy cattle subdistrict of Lembang NBMCU. Each inseminator was targeted of performing six combinations of treatments (frozen semen dose $=3$ levels and $\mathrm{HF}$ bull= 2 heads) in a proportion manner. Inseminators were instructed to record code and date of each straw used. Based on the ability of conducting AI mating on HF dairy cows studied, these six inseminators were considered as inseminator with good skill as indicated by the number of HF acceptors successfully mated by AI mating using the three frozen semen doses.

\section{Pregnancy Detection}

Pregnancy was detected by rectal palpation between 60-90 d after AI mating to check the occurrence of corpus luteum (CL) at the left or the right of ovaries of individual acceptor cow. An acceptor cow was considered coming into pregnant if at any time after $21 \mathrm{~d}$ of $\mathrm{AI}$ mating it was not returned to estrus as well as corpus luteum (CL) was able to be palpated on the ovary after 60-90 days of the AI mating. Instead, a cow was considered unpregnant if signs of estrus returning about $21 \mathrm{~d}$ after AI mating.

\section{Variables of Observation}

Variables of observation were expressed as conception rates $(\mathrm{CR} \%)$ as calculated by a ratio between the number of AI acceptors positively identified pregnant over the total number of AI acceptors in a determining population. As an example, to calculate conception rates of the AI mating acceptors mated by the standard frozen semen dose (L.I) from Farrell bull was obtained by dividing the number of pregnant acceptor to the total number of AI acceptors mated by the standard dose (instead of L.2 and L.3 doses) produced by Farrel bull (instead of Forsa bull).

\section{Sperm Quality}

Sperm quality was examined from the motility of sperms after thawing stated as Post Thawing Motility (PTM). These three frozen sperm doses were collected for testing samplings from sperm containers at Lembang AIA, Lembang NBMCU and from thermos of inseminators in the field. Straws collected from thermos of inseminators were thawed at a right time when AI mating soon being done to estrous acceptors.

\section{Analysis of Data}

Conception rates of $\mathrm{HF}$ cows as $\mathrm{AI}$ acceptors were analyzed by General Linear Model (GLM) for classes with unbalance data. Some GLM were developed by considering one or more factors of frozen semen dose (3), bull (2), inseminator (6) and parity (5) as fixed variables. Initial GLM analysis was performed for all HF cows fulfilling the criteria as AI acceptor in this study. Results showed that all factors did not give significant effects $(\mathrm{P}>0.05)$ on conception rates. However, the inseminators had a very significant effect $(\mathrm{P}<0.01)$ on conception rates.

To determine further inseminator effect, T-test was done for conception rates among inseminators in this study. Based on this initial result, it was known that all of inseminators had good ability in performing AI mating. One inseminator, however, was identified having a very good skill indicated by achieving a high numbers of AI acceptors as well as in resulting high pregnancy rates than others. Conception rates of AI mating acceptors from all inseminators were therefore included in the analysis. While the influence of parity were considered into 5 parities $(1,2,3,4$ and $\geq 5)$. Parity (5) was considered as a fixed variable together with other two factors of bull (2) and frozen semen dose (3).

Possible interaction between two factors were considered, so interaction between dose $\mathrm{x}$ bull was put into the GLM analysis. T-test was conducted to determine significant differences between the average values of conception rates $(\%)$.

\section{RESULTS}

\section{Acceptors by Frozen Semen Dose}

Holstein Fresian (HF) female cows as acceptors of AI mating of three frozen semen doses of $25 \times 10^{6}, 20 \times$ $10^{6}$ and $15 \times 10^{6}$ sperms and two HF bulls of Farrel and Forsa reached a total number of 680 heads. However a number of HF acceptors that fulfilled the criteria to be analyzed for conception rates of the AI acceptors using three frozen semen doses in this study were only 556 heads. The remaining $124 \mathrm{HF}$ cows $(18.2 \%)$ were eliminated as the acceptors. Elimination was considered for some reasons, namely due to these cows of losing code of the frozen semen dose used, returning estrus around $21 \mathrm{~d}$ after AI mating and being dead or sold before pregnancy examination. Another reason was due to reproductive problems such as endometritis, repeat breeder and persistent corpus luteum. 


\section{Acceptors by Bull}

HF acceptors inseminated by frozen semen from Farrel bull amounted for 279 heads (50.2\%), while those from Forsa bull amounted for 277 heads (49.8\%). A minimum number of $\mathrm{AI}$ acceptors for each combination of bull and frozen semen dose was targeted at least 50 heads. From this study, the total number of acceptors inseminated by frozen semen at $25 \times 10^{6}, 20 \times 10^{6}$, and 15 x $10^{6}$ sperms for Farrel bull were 105 heads (18.9\%), 87 heads $(15.6 \%)$, and 87 heads $(15.6 \%)$, respectively; while those for Forsa bull were 83 heads $(14.9 \%), 108$ heads $(19.4 \%)$, and 86 heads $(15.5 \%)$, respectively. Further, the total number of AI acceptors for both of these two bulls at respective frozen semen doses were successively 188 heads (33.8\%), 195 heads (35.1\%), and 173 heads (31.1\%). This showed that the number of AI acceptors for each of dose and bull combination fulfilled the target. Similarly, the number of HF cows as AI acceptors were also proportional for three tested frozen semen doses.

\section{Acceptors by Parity}

The parity or number of a cow giving birth is a condition to indicate a biological maturity of animals. As described earlier in this study, AI mating was targeted to all acceptors within 1- $\geq 5$ parities. The number of the HF cows and heifers as AI mating acceptor were in accordance to the initial target. Most acceptors were within parities of $1,2,3$, and 4 with the respective number of AI acceptors successively 126 heads (22.7\%), 156 heads $(28.1 \%), 147$ heads $(26.8 \%)$, and 88 heads $(15.8 \%)$. A small number of AI acceptors were within 5-8 parities namely 39 heads $(7.0 \%)$. These mature cows were inseminated due to the inseminator did not carry a standard frozen semen straw at the time of estrous cycle, so those estrous cows were inseminated by reduced frozen semen doses. From initial GLM analysis, it was known that parity did not give significant effect on conception rates of AI acceptors. To know the effects of three doses of frozen semen on conception rates of the AI mating acceptors, study was conducted for all AI mating acceptors within $1-\geq 5$ parities.

\section{Acceptors by Inseminator}

The number of AI mating acceptors and their conception rates conducted by six inseminators for the three frozen semen doses are presented in Table 1. Performance of inseminator 1 was the best among the other five inseminators for interm of getting higher AI mating acceptors and conception rates. The total number of $\mathrm{AI}$ acceptors inseminated by this inseminator for those three frozen semen doses were 196 heads (35.3\%) and the average of conception rates was around $81.6 \%$ $89.6 \%$. Whilst the other five inseminators achieved the number of AI acceptors were between 53-126 heads $(9.5 \%-22.7 \%)$ with the conception rates between $43.9 \%-79.7 \%$.

\section{Variance Analysis of Conception Rates}

Conception rates (CR \%) were used as variables to assess the success of AI mating of HF acceptors by using three frozen semen doses in this study. Conception rates become an appropriate indicator to determine the success rates of AI mating, compared for example to the numbers of not returning pregnant or non return rate (NR \%) (Perry et al., 2011). This is because conception rates can be seen in a more definite success of AI acceptors being pregnant, when an individual cow gets pregnancy examination. Conception rates are directly related to the production of which determining productive life of each cow (Saha et al., 2014). Conception rate (CR \%) was formulated as a result of the ratio between the number of pregnant acceptors to the number of all inseminated acceptors for any certain population.

Results from variance analysis of the GLM were consistent for the classified groups that only inseminator gave significant effect $(\mathrm{P}<0.05)$ on conception rates (\%) of AI mating acceptors. By contrast, frozen semen dose, bull as well as interaction of dose with bull and of dose with inseminator were not statistically significant $(\mathrm{P}>0.05)$ on conception rates of the AI acceptor (Adj. $\mathrm{R}^{2}$ models $=10.32 \%$ ). As was previously described, differences in conception rates among inseminators occurred as one inseminator (Inseminator 1) had very good skill in $\mathrm{AI}$ mating and in gaining conception rates than the other inseminators.

\section{DISCUSSION}

\section{Role of Inseminator in Artificial Insemination Mating}

Inseminator as an executor of AI mating is one of the key factors in determining the success of pregnancy

Table 1. Conception rates (\%) of artificial insemination mating acceptors by semen dose and inseminator

\begin{tabular}{|c|c|c|c|c|c|c|}
\hline \multirow[b]{2}{*}{ Inseminator } & \multicolumn{6}{|c|}{ Dose of frozen semen per volume 0.25 cc } \\
\hline & $\begin{array}{c}\text { Acceptor } \\
\text { (head) }\end{array}$ & $\begin{array}{c}25 \times 10^{6} \\
\text { Dose }\end{array}$ & $\begin{array}{c}\text { Acceptor } \\
\text { (head) }\end{array}$ & $\begin{array}{c}20 \times 10^{6} \\
\text { Dose }\end{array}$ & $\begin{array}{c}\text { Acceptor } \\
\text { (head) }\end{array}$ & $\begin{array}{c}15 \times 10^{6} \\
\text { Dose }\end{array}$ \\
\hline Ins. 1 & 84 & $81.6 \pm 4.0$ & 61 & $86.4 \pm 3.4$ & 51 & $89.6 \pm 3.6^{\mathrm{ns}}$ \\
\hline Ins. 2 & 20 & $78.1 \pm 4.1$ & 19 & $63.3 \pm 4.9$ & 23 & $45.7 \pm 5.0^{\mathrm{ns}}$ \\
\hline Ins. 3 & 49 & $45.0 \pm 5.3$ & 40 & $79.7 \pm 4.1$ & 37 & $70.7 \pm 4.9^{\text {ns }}$ \\
\hline Ins. 4 & 33 & $75.2 \pm 4.5$ & 16 & $51.4 \pm 5.1$ & 17 & $71.6 \pm 4.6^{\mathrm{ns}}$ \\
\hline Ins. 5 & 24 & $43.5 \pm 5.1$ & 14 & $59.4 \pm 5.0$ & 15 & $52.2 \pm 5.1^{\mathrm{ns}}$ \\
\hline Ins. 6 & 20 & $64.9 \pm 5.2$ & 17 & $51.0 \pm 5.0$ & 18 & $67.9 \pm 4.8^{\mathrm{ns}}$ \\
\hline
\end{tabular}

Note: ns showed average values at the same row were not statistically significant $(\mathrm{P}>0.05)$ 
rates of AI acceptors. The number of HF acceptors inseminated among individual inseminator varied. Initial analysis of General Linear Model (GLM) considering the fixed factors of doses of frozen semen (3), bull (2), inseminator (6) and parity (5) proved that inseminators gave a very significant effect $(\mathrm{P}<0.01)$ on the pregnancy rates of $\mathrm{AI}$ acceptors (Total $\mathrm{R}-\mathrm{Sq}=6.58 \%$ ). Inseminator 1 was identified for having a very good AI mating skill compared to those other five inseminators as indicated either by high number of AI mating acceptors or by high pregnancy rate (Table 1). However, the number of AI acceptors and conception rates achieved by this inseminator were proportional for each of those three frozen semen doses.

Previous examination on the effects of inseminator for AI success as reported by Sarder (2006) showed working experiences of an inseminator gave a significant impact on conception rates of AI acceptors. Inseminator categorized as a professional inseminator with good ability and experiences had a better AI success rates than the other less skill and experiences inseminators. Inseminator was identified as one factor that could give effect to on conception rates of the AI acceptors beside the other factors such as farm management, lambing period, lambing interval and peak milk production (Buckley et al., 2004). Inseminator with a good experience and skill leads to a good guarantee for a successful AI mating beside of quality of frozen semen, right time of insemination and health status of acceptors (Drost, 2007). Variation on the performances among inseminators to make acceptors becoming pregnant were directly influenced by their skill and experiences. The more skill and the longer experiences of inseminator increased fertility rates of acceptors being successfully pregnant (Herawati et al., 2012).

\section{Quality Test of Frozen Semen}

Proper assessment of post thawing sperm quality is an important aspect to achieve a high success rate of AI mating, since it can provide insights upon fertilizing capacity of cryopreserved spermatozoa (Januškauskas \& Žilinskas, 2002). Many processes of frozen semen since dilution, chilling, freezing, storage, transportation and thawing for AI mating could affect the viability and fertilization capacity of spermatozoa (Saha et al., 2014; Muiño et al., 2015). According to Arifiantini et al. (2005) the success of using frozen semen to AI mating could be seen from the values of recovery rate (RR), as the expression of the number of spermatozoa successfully recovered from the freezing process and the number of survival spermatozoa in vitro after thawing that was called longevity.

To check the feasibility of frozen semen quality after thawing was conducted by collecting sampling tests of straws of the three different frozen semen doses storaged at Lembang AIA, AI containers at Lembang NBMCU and AI thermos of inseminator in the field. Quality test of frozen semen was evaluated through the thawing process by following a standard procedure (Lembang AIA, 2011). Shrivatava (2013) suggested that frozen-thawed semen may be safely used for artificial insemination up to 15 min by keeping frozen-thawed semen straw either at $4{ }^{\circ} \mathrm{C}$ or at warm water at $30{ }^{\circ} \mathrm{C}$ after thawing of frozen semen at $37^{\circ} \mathrm{C}$ for $30 \mathrm{~s}$.

Based on the provisions of National Standardization Agency of Indonesia (BSN, 2008) of the quality requirements in producing frozen semen among others are to be unpermitted of containing microorganisms in causing infectious diseases, spermatozoa motility at least $40 \%$ and degree of movement of individual spermatozoa at least 2 at the time of frozen semen thawed. Results from this study generally showed that after thawing frozen semen in container storage at Lembang AIA had an excellent quality of sperms and very feasible for AI mating. Results of thawing frozen semen from Forsa bull and Farrell bull at each sperm dose $\left(25 \times 10^{6}\right.$, $20 \times 10^{6}$, and $15 \times 10^{6}$ sperms) showed the movement of individual spermatozoa at the scores between 2-3 and PTM between 40-45. Similarly, the results of thawing frozen semen from a container at Lembang NBMCU for each treatment and bull showed individual sperm motility at the scores between 2-3 and PTM between 40-45.

Sampling test moreover were extended at field conditions providing in the villages of Cibodas (Forsa bull), Pojok (Farrel and Forsa bulls) and Pasar Kemis (Forsa bull). The test results also gave sperm quality after thawing similar to the previous tests at Lembang AIA and Lembang NBMCU. Individual spermatozoa movement was on the score of 2-3 and PTM between 40-45. All of these results showed an indication of good handling processes were conducted for three different frozen semen doses of straws along phases of distributions and storages. One crucial factor in affecting the storage of frozen semen straws is the availability of sufficient liquid $\mathrm{N}_{2}$ in a container. A study in central dairy cows in Pakistan proved without the addition of liquid $\mathrm{N}_{2}$ at 2 liter capacity in stored frozen semen containers resulted deterioration of sperm motility after 10 -d storage times (Das et al., 2002). Thus the availability of liquid $\mathrm{N}_{2}$ had to be guaranted properly along the process of distributions and storages of three frozen semen doses in this study.

Microscopic examination of cattle in Poland found spermatozoa with normal morphology by 50\% from where those progressive movements by $80 \%$ did not lead to morphological changes (Barszcz et al., 2012). According to López-Gatius (2012) at field conditions, post thawing of frozen semen gave good results for AI mating in exotic beef cattle by the achievement of average motility by $38.0 \pm 2.74 \%$, proportion of life semen by $45.2 \pm 9.86 \%$ and abnormal semen by $6.0 \pm 2.83 \%$.

\section{Conception Rates of Artificial Insemination Mating Acceptors}

Study of the effectiveness of the AI mating based on the treatments on reducing doses of frozen semen per 0.25 cc volume for the AI mating acceptors is presented in Table 2. All of three straws containing frozen sperm doses of $25 \times 10^{6}, 20 \times 10^{6}$, and $15 \times 10^{6}$ sperms did not statistically give significant effects on conception rates of HF cows as the AI mating acceptors. By decreasing frozen semen concentration up to $20 \times 10^{6}$ sperms per $0.25 \mathrm{~mL}$ straws resulted conception rates of the accep- 
Table 2. Conception rates (\%) of artificial insemination mating acceptors by semen dose

\begin{tabular}{lcccccc}
\hline & \multicolumn{5}{c}{ Dose of frozen semen per volume 0.25 cc } \\
\cline { 2 - 7 } & $\begin{array}{c}\text { Acceptor } \\
\text { Bull }\end{array}$ & $\begin{array}{c}25 \times 10^{6} \\
\text { Dose }\end{array}$ & $\begin{array}{c}\text { Acceptor } \\
\text { (head) }\end{array}$ & $\begin{array}{c}20 \times 10^{6} \\
\text { Dose }\end{array}$ & $\begin{array}{c}\text { Acceptor } \\
\text { (head) }\end{array}$ & $\begin{array}{c}15 \times 10^{6} \\
\text { Dose }\end{array}$ \\
\hline Farrel & 105 & $60.0 \pm 5.4^{\mathrm{ns}}$ & 87 & $62.1 \pm 4.8^{\mathrm{ns}}$ & 87 & $71.3 \pm 5.2^{\mathrm{ns}}$ \\
Forsa & 83 & $69.4 \pm 5.8^{\mathrm{ns}}$ & 108 & $68.3 \pm 4.6^{\mathrm{ns}}$ & 86 & $61.2 \pm 6.0^{\mathrm{ns}}$ \\
Total & 188 & $64.7 \pm 4.5^{\mathrm{ns}}$ & 195 & $65.2 \pm 3.4^{\mathrm{ns}}$ & 173 & $66.3 \pm 4.3^{\mathrm{ns}}$ \\
\hline
\end{tabular}

Note: ns showed average values at the same row were not statistically significant $(\mathrm{P}>0.05)$.

tors as well as to the standard frozen semen. A further declining of sperm concentration to $15 \times 10^{6}$ sperms per straw was still capable of maintaining conception rate similar to the previous sperm concentration, even it was still able to maintain CR similar to the standard dose of 25 million sperms.

Further investigation on conception rates of $\mathrm{HF}$ acceptors by considering individual bull proved also that by decreasing concentration of the standard frozen semen dose to two reduced doses of $20 \times 10^{6}$ sperms and $15 \times 10^{6}$ sperms did not give significant effects on conception rates of these AI acceptors. Conception rates of the AI acceptors as the joining of these two bulls also gave consistent results, from which by reducing frozen semen doses up to the two lower levels provided similar conception rates to the standard one. Conception rates of the AI acceptors for semen doses of $25 \times 10^{6}, 20 \times 10^{6}$, and $15 \times 10^{6}$ sperms were $64.7 \pm 4.5 \%, 65.2 \pm 4.6 \%$, and $66.3 \pm 4.3 \%$, respectively.

In relation to these results, Saha et al. (2014) reported that the genetic composition of bulls as frozen semen producers gave no significant effect on conception rates, namely in the range of $50.0 \%-77.8 \%$. Based on these results, it could be stated that $\mathrm{AI}$ mating by reducing doses of frozen semen up to a lowered level containing 15 million sperm per 0.25 cc could maintain conception rates of the AI acceptors as well as by using frozen semen at the standard dose. This was applicable for all ages of the AI mating acceptors.

\section{CONCLUSION}

Conception rates of HF acceptors by frozen-semen AI mating using the two reducing sperm doses $\left(20 \times 10^{6}\right.$ and $15 \times 10^{6}$ sperms) gave similar success rates to the standard one $\left(25 \times 10^{6}\right.$ sperms $)$ per $0.25 \mathrm{cc}$.

\section{ACKNOWLEDGEMENT}

The deepest appreciation was addressed to Prof. (R). Dr. Kusuma Diwyanto, MSc. for his great idea and support for this research, Drh. Meidaswar, MSc. as Head of Lembang AIA and staffs for their funding and AI facilities, also Drs. Dedi Setiadi as Director and Drh. Ramdhan as Secretary of KPSBU Lembang for good collaboration and coordination for this AI field research in Lembang District, West Java.

\section{REFERENCES}

Anderson, M., J. Taponen, E. Koskinen, \& M. Dahlbom. 2004. Effect of insemination with doses of 2 or 15 million frozenthawed spermatozoa and semen deposition site on pregnancy rate in dairy cows. Theriogenology 61: 1583-1588. http://dx.doi.org/10.1016/j.theriogenology.2003.09.006

Andrabi, S., M. H., M. Siddique, N. Ullah, \& A. Khan. 2006. Effect of reducing sperm numbers per insemination dose on fertility of cryopreserved buffalo bull semen. Pakistan Vet. J.. 2006. 26: 17-19.

Arifiantini, R. I., B. Purwantara, \& M. Riyadhi. 2010. Occurence of sperm abnormality of beef cattle at several Artificial Insemination Centers in Indonesia. Anim. Prod. 12: 44-49.

[BSN] National Standardization Agency of Indonesia (in Indonesian: Badan Standardisasi Nasional). 2008. Semen Beku -Bagian 1: Sapi. SNI 4869.1:2008. http://sisni.bsn. go.id/index.php?/sni_main/sni/detail_sni/7026. Diakses tanggal 12 Desember 2013.

Barszcz, K., D. Wiesetek, M. Wąsowicz, \& M. Kupczyńska. 2012. Bull semen collection and analysis for artificial insemination. J. Agr. Sci. 4: 1-10.

Bhakat, M., T. K. Mohanty, V. S. Raina, A. K. Gupta, \& H. M. Khan. 2011. Frozen semen production performance of murrah buffalo bulls. Buffalo Bulletin 30: 157-162.

Bucher, A., R. Kasimanickam, J. B. Hall, J. M. Dejarnette, W. D. Whittier, W. Kähn, \& Z. Xu Z. 2009. Fixed-time AI pregnancy rate following insemination with frozen- thawed or fresh-extended semen in progesteronesupplemented COSynch protocol in beef cows. Theriogenology 71: 1180-1185. http://dx.doi.org/10.1016/j.theriogenology.2008.12.009

Buckley, F., J. Mee, K. O'sullivan, R. Evans, D. Berry, \& Patdillon. 2004. Insemination factors affecting the conception rate in seasonal calving Holstein-Friesian cows. Reprod. Nutr.Dev. 43: 543-555.

Das. B. C., S. Habib, M. Chowdhury, M. I. Hossain, \& M. H. Islam. 2002. Qualitative changes of frozen bull smeen under field conditions in Bangladesh. Pakistan J. Biological Sci. 5: 481-483. http://dx.doi.org/10.3923/pjbs.2002.481.483

DeJarnette, J. M., C. R. McCleary, M. A. Leach, J. F. Moreno, R. L. Nebel, \& C. E. Marshall. 2010. Effects of 2.1 and $3.5 \times$ $10^{6}$ sex-sorted sperm dosages on conception rates of Holstein cows and heifers. J. Dairy Sci. 93: 4079-4085. http:// dx.doi.org/10.3168/jds.2010-3181

Drost, M. 2007. Bubaline versus bovine reproduction. Theriogenology 68: 447-449. http://dx.doi.org/10.1016/j.theriogenology.2007.04.012

Frijters, A. C. J., E. Mullaart, R. M. G. Roelofs, R. P. van Hoorne, J. F. Moreno, O. Moreno, \& J. S. Merton. 2009. What affects fertility of sexed bull semen more, low sperm dosage or the sorting process?. Theriogenology 71:64-67. http://dx.doi.org/10.1016/j.theriogenology.2008.09.025

Herawati, T., A. Anggraeni, L. Praharani, D. Utami, \& A. Argiris. 2012. Peran inseminator dalam keberhasilan inseminasi buatan pada sapi perah inseminator role in the suc- 
cess of artificial insemination on dairy cattle. Informatika Pertanian 21: 81-88.

Januškauskas, A. \& H. Žilinskas. 2002. Bull semen evaluation post-thaw and relation of semen characteristics to bull's fertility. Veterinarija Ir Zootechnika. T. 17: 1-9.

Larson, J. E., G. C. Lamb, B. J. Funnell, S. Bird, A. Martins, \& J. C. Rodgers. 2010. Embryo production in superovulated Angus cows inseminated four times with sexed-sorted or conventional, frozen-thawed semen. Theriogenology. 73:698-703. http://dx.doi.org/10.1016/j.theriogenology.2009.11.009

Lembang AIA (BIB Lembang). 2011. Proses Produksi Semen Beku. Buku Pintar Inseminasi Buatan. Balai Inseminasi Buatan (BIB) Lembang. Ditjen Peternakan dan Kesehatan Hewan. Kemen Pertanian, Lembang.

López-Gatius, F. 2012. Factors of a noninfectious nature affecting fertility after artificial insemination in lactating dairy cows: a review. Theriogenology 77:1029-1041. http:// dx.doi.org/10.1016/j.theriogenology.2011.10.014

Muiño, R., A. I. Peña, L. A. Quintela, J. Becerra, P. Herradón, \& F. H. Gonzale. 2015. Management of the storage of cryopreserved sperm on dairy cattle farms. Biotechnology in Animal Husbandry 31: 85-100. http://dx.doi.org/10.2298/ BAH1501085M

Perry, M. J., S. A. Venners, X. Chen, X. Liu, G. Tang, H. Xing, D. B. Barr, \& X. Xu. 2011. Organophosphorous pesticide exposures and sperm quality. Reprod. Toxicol. 31:75-79. http://dx.doi.org/10.1016/j.reprotox.2010.08.006
Sá Filho, M. F., H. Ayres, R. M. Ferreira, M. Nichi, M. Fosado, F. E. P. Campos, \& P. S. Baruselli. 2010. Strategies to improve pregnancy per insemination using sex-sorted semen in dairy heifers detected in estrus. Theriogenology 74:1636-1642. http://dx.doi.org/10.1016/j.theriogenology.2010.06.036

Saha R., A. Ashraf, \& Z. Rahman. 2014. Comparative Study on Conception Rate of Cow in Using Frozen and Liquid Semen. J. Anim. Sci. Adv. 4: 749-772.

Sarder, M. J. U. 2006. Study on the influence of sire on reproductive and productive capability of dairy cows used for artificial insemination programme at greater Rajshahi district. Rajshahi University Studies, Part-B. Journal of Science 34: 237-253.

Schenk, J. L., D. G. Cran, R. W. Everett, \& G. E. Seidel. 2009. Pregnancy rates in heifers and cows with cryopreserved sexed sperm: Effects of sperm numbers per inseminate, sorting pressure and sperm storage before sorting. Theriogenology 71:717-728. http://dx.doi.org/10.1016/j.theriogenology.2008.08.016

Seidel, G. E. \& J. L. Schenk. 2008. Pregnancy rates in cattle with cryopreserved sexed sperm: Effects of sperm numbers per inseminate and site of sperm deposition. Anim. Reprod. Sci. 105: 129-38. http://dx.doi.org/10.1016/j.anireprosci.2007.11.015

Shrivatava, N., M. K. Awasthi, S. B. Sahu, S. Sahastrabudhe, \& R. P. Tiwa. 2013. Effect of Incubation Period at $30{ }^{\circ} \mathrm{C}$ and at $40{ }^{\circ} \mathrm{C}$ on Postthaw Characteristics of Frozen Semen of Hf Crossbred Bulls. Indian Journal of Animal Reproduction 34: 22-25. 